\title{
MAGDALENA PAEKA \\ Problem badań więzi wewnątrzrodzinnej w bezrobotnych rodzinach wielkomiejskich
}

Na historię życia domowego nieuchronnie wpływ miały procesy ewolucji, które zmieniały tradycyjna moralność i problemy życia prywatnego, jak: prawa i obowiązki męża i żony, ich władzę nad dziećmi czy możliwość rozwodu ${ }^{1}$. Rodzina stawała się tym mocniejsza im bardziej potrafiła bronić się przed nowinkami i szybkimi zmianami społeczeństwa. Jednak w wyniku wielu przemian społeczno-ekonomicznych i politycznych, które dokonały i nadal dokonują się w naszym kraju, nadal dochodzi do licznych zmian w strukturze rodziny. Okresowi transformacji często towarzyszy w środowisku rodzinnym stan nieufności i bierności, a wyraża się on poprzez zwątpienie rodziców w swoją siłę oddziaływania i możliwość przekazywania wartości szczególnie przez nich cenionych. Przemiany te sa związane także $z$ bezrobociem, które poczatkowo było wiązane przez społeczeństwo $z$ nadzieją na nadanie odpowiedniej rangi kwalifikacjom i zdolnościom stanowiącym podstawę do polepszenia statusu materialnego. Jednak oczekiwania te nie sprawdziły się, co spowodowało pogłębienie frustracji oraz wzrost patologicznego zachowania. Ze względu na trudności na rynku pracy w rodzinach, w których mężowie utracili swoją dotychczasowa pracę, obserwuje się tendencje do wzmożonej aktywności zarobkowej u żon. Bezrobocie wywołało liczne zmiany w ustalonym trybie i porządku dnia codziennego. Doprowadziło także do zmian w zakresie pełnionych ról rodzicielskich, m.in. do osłabienia pozycji męża-ojca, który wcześniej był osobą najważniejszą w rodzinie $z$ racji odpowiedzialności za byt jej członków².

${ }^{1}$ J. L. F 1 a n d r i n: Historia rodziny. Warszawa 1998.

${ }^{2}$ J. A. P i e l k o w a: Zmiany w pełnieniu funkcji socjalizacyjnej w rodzinie. W: Wspótczesne rodziny polskie - ich stan i kierunek przemian. Red Z. T y s z k a. Poznań 2001 s. 256-257. 
Więź rodzinna ma swoje najgłębsze podstawy w świadomości jednostek, ich łączności $\mathrm{z}$ innymi osobami $\mathrm{w}$ rodzinie i poczuciu przynależności do rodziny jako odrębnej grupy społecznej. Więzi wytwarzają w jednostce wspólną lub odmienną postawę wobec tych samych wartości, norm, ocen, osób, zdarzeń itp. Za Leonem Dyczewskim więź rodzinną będę traktować jako kompleks sił przyciągających jej czlonków nawzajem do siebie i wiązących ich ze sobą. Sily te, jak pisze dalej Leon Dyczewski wynikają ze związku małżeńskiego, świadomości związków genetycznych, przeżyć emocjonalnych, współdziałania, a także z uwarunkowań społecznych, kulturowych i gospodarczych, w jakich żyje dana rodzina. Więź rodzinna nie jest jednakowa we wszystkich rodzinach. Jest ona nieco odmienna w różnych fazach cyklu życia tej samej rodziny lub w różnych okolicznościach jej życia. Więź rodzinna jest zjawiskiem dynamicznym i ulega ciągłym przeobrażeniom. Leon Dyczewski dokonuje też próby określenia poszczególnych rodzajów więzi rodzinnej i wyróżnia trzy specyficzne ich zespoły.

Pierwszy zespól odnosi się do stosunków między pokoleniami. Ich treść koncentruje się wokół wychowania dzieci, autorytetu rodziców i udzielania wzajemnej pomocy. Podłożem tych stosunków jest wspólnota mieszkaniowa i gospodarcza. Stosunki te ściśle lączą się ze strukturą rodziny i współdziałaniem jej czlonków, dlatego więź, jaka w wyniku ich powstaje, może być nazwana więzią strukturalno-przedmiotową.

Drugi zespół stanowią stosunki między osobami, które opierają się na sferze intelektualnej. Ich treścią są myśli, uczucia, aspiracje, pragnienia oraz wzajemne postawy, jakie zajmują wobec siebie poszczególni członkowie rodziny. W oparciu o ten zespół stosunków tworzy się miedzy członkami rodziny więź osobowa.

Zespół trzeci stanowią stosunki między osobami w rodzinie, których treścią są postawy zgodności lub niezgodności wobec tych samych wartości, norm, wzorów ${ }^{3}$. Dlatego też każda rodzina ma właściwy sobie sposób spędzania wolnego czasu, wakacji organizowania przyjęć towarzyskich. Każda rodzina tworzy własną tradycję, historię i tworzy własną przyszłość. Więź, jaka wytwarza się w oparciu o te czynniki, można nazwać więzią kulturową.

Omawiając przemiany więzi wewnątrzrodzinnej w wielkomiejskich rodzinach bezrobotnych, trzeba zwrócić szczególną uwage na szereg różnych zjawisk, które mają wpływ na zmianę wizerunku współczesnej rodziny polskiej. Zdaniem Zbigniewa Tyszki, w rodzinach epoki postindustrialnej obserwujemy następujące procesy: wzrost zatrudnienia kobiet, egalitaryzacja ról w małżeń-

${ }^{3}$ L. D y c zew s k i: Zmiany w spójności więzi międzypokoleniowej w rodzinie. W: Przemiany rodziny polskiej. Red. J. Ko m o row s ka. Warszawa 1975; por. Te nż e: The family in a transforming society. Lublin 1999. 
stwie i rodzinie, relatywny spadek wartości dzieci w ocenach rodziców, dyferencjacja norm i wartości u poszczególnych członków rodziny, indywidualizacja form aktywności w rodzinie, autonomizacja członków rodziny, osłabienie spójności i dezintegracja znacznej części rodzin, wzrost liczby konfliktów małżeńskich i rozwodów, patologizacja społeczna i psychospoleczna części jednostek ${ }^{4}$.

Wyrazem powyższych zjawisk są zmiany w sposobach myślenia ludzi o rodzinie, o jej roli w życiu jednostki oraz spoleczeństwa. W sferze życia rodzinnego, obok pozytywnych efektów tych przemian, pojawiło się wiele niebezpiecznych zjawisk, które w pewnych kontekstach moga prowadzić do destabilizacji, dysfunkcji, a nawet do dezintegracji rodziny, np. pod wpływem długotrwałego bezrobocia w kraju, albo środowisku lokalnym, także wielkomiejskim.

\section{Założenia teoretyczno-metodologiczne}

Badania rodziny oraz przemian, które w niej zachodzą są odbiciem zarówno mikrostrukturalnych, jak i makrostrukturalnych przeobrażeń występujących w danym społeczeństwie, w danej kulturze i społecznej mentalności. Rodzina budzi coraz większe zainteresowanie wśród uczonych, a także troskę u polityków o jej podstawowe warunki egzystencji oraz przyszłość. Niektórzy badacze zwracają szczególną uwage na znaczenie egzystencjonalne tej mikrogrupy społecznej, podkreślając wspólne uczucia, doznania oraz ludzkie odniesienia, w tym najbardziej prywatnym świecie jednostki ${ }^{5}$.

Na mikrostruktury społeczne oraz ich uklad oddziałuje nie tylko aktualny stan społeczeństwa globalnego, ale także jego przeszłość, a więc procesy, które rozgrywały się w przeszłości, formułując wzory społeczne regulujące funkcjonowanie mikrogrup, ról spolecznych występujących w ich ramach oraz charakter i siłę więzi społecznych. Ciekawe podejście do wzorów społecznych, przydatne w interpretacji przemian zachodzących w bezrobotnej rodzinie wielkomiejskiej, prezentuje Zbigniew Tyszka ${ }^{6}$. Wyróżnia on wzory ogólnospoleczne, które reguluja funkcjonowanie określonego typu mikrogrup oraz ich podsystemów i elementów składowych, takich, jak: role społeczne, więzi, modele świadomościowe, wewnątrzgrupowy system wartości. Wzory te mogą również dotyczyć wzajemnych odniesień między mikrogrupami w ramach mikrostruktury społecznej.

\footnotetext{
${ }^{4}$ Z. T y s zk a: System metodologiczny poznańskiej szkoly socjologicznych badań nad rodzinq, Poznań 1997 s. 99.

${ }^{5}$ Przykładem takiego stanowiska jest artykuł Z. T y s z k i: Stan i przeobrażenia rodzin polskich na przełomie wieków XX i XXI. Niedawna przeszłość i teraźniejszość. W: Wspólczesne rodziny polskie - ich stan i kierunek przemian. Red. Z. T y s z k a. Poznań 2001 s. 15-24.

${ }^{6}$ Z. T y s z k a: Mikrosocjologia - mikrostruktura - rodzina. "Roczniki Socjologii Rodziny”. T. 5: 1993 s. $9-10$.
} 
Do tych samych przedmiotów odnoszą się wzory subkulturowe, które są uksztaltowane są nie tylko przez wplywy globalne ale również przez określoną makrostrukturę czy mezostrukturę, np. przez wplyw regionu lub określony typ miejscowości. Z kolei wzory indywidualne sa wypracowane $\mathrm{w}$ ramach konkretnej mikrostruktury i wynikaja z niepowtarzalnej sytuacji grupy, jej niepowtarzalnych cech oraz z cech osobowości jej członków.

We wlasnych badaniach socjologicznych zrealizowanych w czasie seminarium magisterskiego pod kierunkiem prof. Zbigniewa Tyszki w Instytucie Socjologii Uniwersytetu im. Adama Mickiewicza w Poznaniu zajęłam się uwarunkowaniami struktury wielkomiejskich rodzin bezrobotnych, które legitymowały się wykształceniem podstawowym i zasadniczym zawodowym. Problem główny tych badań uwzględniał także, zgodnie z koncepcją metodologiczną Z. Tyszki, kwestię świadomości rodzinnej, czyli układ subiektywnych odniesień jednostki do własnej rodziny, jak i do rodziny, w ogóle, bez konkretnej adresacji. Świadomość rodzinna obejmuje, zdaniem, Z. Tyszki, z jednej strony „całość” rodziny, a z drugiej strony również podstawowe jej elementy: role, funkcje, pozycje społeczne czlonków, więzi i reguly wspólżycia rodzinnego.

Można mówić tutaj o poglądach, opiniach, przekonaniach, postawach, dokonywanych wartościowań, ocen oraz modeli świadomościowych ${ }^{7}$.

W świetle tego zasadniczy problem badawczy zawiera się w pytaniach:

- Czy współczesna rzeczywistość społeczno-ekonomiczna sprzyja pełnieniu funkcji rodzicielskich?

- Czy właściwemu funkcjonowaniu wielkomiejskich rodzin bezrobotnych zagraża brak określonego wzorca wychowawczego i socjalizacyjnego?

$\mathrm{Na}$ ich podstawie sformulowałam następujące hipotezy ogólne:

- Współczesna rzeczywistość społeczno-ekonomiczna nie sprzyja pełnieniu funkcji rodzicielskich.

- Wielkomiejskie rodziny bezrobotne maja problem w określeniu wzorca wychowawczego i socjalizacyjnego.

Weryfikacji powyższych hipotez służył wybrany element struktury rodziny taki jak: wzajemne ustosunkowanie postaw członków rodziny do siebie.

Badania zrealizowane zostały w Poznaniu w styczniu 2002 r. na próbie liczacej 112 rodzin prokreacji bezrobotnych mężów z wykształceniem podstawowym i zasadniczym zawodowym. Brano pod uwage rodziny pełne, składające się z męża i żony oraz dzieci (przynajmniej jedno dziecko powinno być na utrzyma-

${ }^{7}$ Z. T y s z k a: System metodologiczny, dz. cyt., s. 40 . 
niu rodziców). Odbywały się one w środowisku wielkomiejskim, które posiada swoją specyfikę, odróżniając się przy tym od innych środowisk. Do charakterystycznych cech wielkiego miasta można zaliczyć m.in. dużą anonimowość i ruchliwość mieszkańców, atomizację życia mieszkańców oraz znaczną tolerancyjność dla różnego rodzaju zachowań. Przyjętą w badaniach metodą badawczą byl wywiad socjologiczny, a podstawową techniką zbierania materiału wywiad przeprowadzony na podstawie skonstruowanego dla tych badań kwestionariusza. Czas przeciętnego wywiadu zajmował ok. 20-30 minut rozmowy. Wywiad ten przeprowadzano w domu respondenta. Brał w nich udział mąż oraz żona, bez udziału innych członków rodziny. Przypadki odmowy wzięcia udziału w wywiadzie były częste, ale ci respondenci, którzy zgodzili się wziąc udział w badaniach, podchodzili do nich z życzliwością i starali się rzetelnie odpowiadać na pytania. Wszystkie wywiady były anonimowe. Uzupełnieniem wywiadu socjologicznego jako metody badawczej było studium przypadku. Uzyskane w ten sposób dane poddano analizie quasistatystycznej, bez udziału danych procentowych, ze względu na zbyt małą liczebność obranej próby, która obejmowała dwie rodziny.

Zmienną niezależną $\mathrm{w}$ badaniach bylo bezrobocie. Jedną z istotnych zmiennych zależnych zastosowanych $\mathrm{w}$ badaniach jest więź wewnatrzrodzinna. Otrzymany materiał badawczy poddano analizie ilościowej i jakościowej.

\section{Przekaz wartości wewnątrz diady małżeńskiej}

Proces kształtowania się więzi rozpoczyna się z chwila tworzenia rodziny. Partnerzy wnoszą do małżeństwa takie czynniki więzi jak: wzajemna miłość, cechy charakteru, cechy spoleczne (pochodzenie, wykształcenie, zawód, system wartości, warunki materialne. Po zawarciu małżeństwa wspólnie wypracowuja dalsze elementy więzi: wzajemną wyrozumiałość i tolerancję, zaufanie, wspólne cele i zainteresowania a także właściwy dobór seksualny i posiadanie dzieci. Siły tworzace więź rodzinną wynikają $\mathrm{w}$ dużej mierze $\mathrm{z}$ istoty małżeństwa, a także $\mathrm{z}$ przeżyć emocjonalnych, wzajemnych stosunków i zależności, postaw wobec uwarunkowań społecznych, kulturowych i gospodarczych, w których żyje rodzi$n a^{8}$.

W panującym obecnie systemie ideologii rodzinnej staje się coraz powszechniejsze racjonalne podejście do prokreacji, wyrażającej się m.in. planowaniem rodziny. W historii populacji ludzkich za potrzeba posiadania dzieci

${ }^{8}$ A. M i n k i ew i c z: Więź rodzinna i czynniki, które ja kształtuja. „Problemy Rodziny”. R. 1993 nr 5 s. $14-17$. 
przemawiały różne względy: religijne, ekonomiczne, prestiżowe itp. Dzieci w takiej sytuacji stanowily wartość instrumentalna, prowadzącą do realizacji różnorodnych i istotnych dla malżonków celów. Współcześnie dażenie do posiadania dziecka jest dążeniem naturalnym, a racje jego bytu wyznaczaja przede wszystkim potrzeby nieinstrumentalne rodziców m.in. potrzeby osobowościowe. Jednak trzeba zwrócić uwage na fakt wzrastających potrzeb materialnych czlowieka, w wyniku których dziecko może stać się przedmiotem jego ekonomicznej kalkulacji. Rodziny często pragną podnieść poziom swojego życia ograniczając liczbę dzieci. Ograniczenie liczby potomstwa może jednak nie wynikać tylko z walki pomiędzy dobrami materialnymi i potrzebami rodzicielskimi, ale może być wynikiem chęci polepszenia warunków materialno-bytowych dzieci już urodzonych $^{9}$. Znaczenie dziecka $\mathrm{w}$ rodzinie określane jest więc $\mathrm{z}$ jednej strony przez czynniki obiektywne, m.in. społeczne, ekonomiczne i demograficzne, a z drugiej strony przez czynniki indywidualne, subiektywne.

\section{Dzietność}

Liczba dzieci w rodzinie wiąże się $\mathrm{z}$ tendencją występującą we współczesnym społeczeństwie. Sposób ujmowania obecności dziecka $w$ rodzinie i jego roli jaką pełni w rodzinie, a tym bardziej w obrębie diady malżeńskiej zróżnicowane jest przez wiele czynników, m.in. sytuację ekonomiczną. Badani wielkomiejscy bezrobotni pytani o deklarowaną chęć dzietności rodziny podali następujące odpowiedzi: 2 dzieci 59,8\%, 3 dzieci i więcej 26,8\%, 1 dziecko 12,5\%, bezdzietna $0 \%$.

Z przedstawionych danych tych wynika, że najbardziej, badanym respondentom odpowiada rodzina $z$ dwojgiem dzieci - 67 respondentów tak odpowiedziało. W drugiej kolejności badani wybrali rodzinę wielodzietną, potwierdziło to 30 respondentów, rodzina $\mathrm{z}$ jednym dzieckiem wybrało 14 bezrobotnych. Żaden z respondentów nie przejawiał chęci posiadania rodziny bezdzietnej.

Tabela nr 1. Deklarowana chęć dzietności wg opinii męża

\begin{tabular}{||l|c|c|c|c|c|c|c|c|c|c||}
\hline \hline \multirow{2}{*}{$\begin{array}{c}\text { Jak rodzina } \\
\text { najbardziej } \\
\begin{array}{l}\text { Panu odpo- } \\
\text { wiada? }\end{array}\end{array}$} & \multicolumn{2}{|c|}{ Bezdzietna } & \multicolumn{2}{|c|}{1 dziecko } & \multicolumn{2}{|c|}{2 dzieci } & \multicolumn{2}{|c|}{$\begin{array}{c}3 \text { dzieci } \\
\text { i więcej }\end{array}$} & \multicolumn{2}{|c|}{ Brak odpowiedzi } \\
\cline { 2 - 11 } & $\%$ & $\mathrm{~L}$ & $\%$ & $\mathrm{~L}$ & $\%$ & $\mathrm{~L}$ & $\%$ & $\mathrm{~L}$ & $\%$ \\
\hline $\mathrm{N}=112$ & 0 & 0 & 14 & 12,5 & 67 & 59,8 & 30 & 26,8 & 1 & 0,9 \\
\hline
\end{tabular}

Żródło: Badania własne

${ }^{9}$ K. S l a n y: Dziecko jako wartość w życiu rodziny (na przykładzie wybranych teorii plodności). „Problemy Rodziny”. R. 1989 nr 5 s. 3-9. 
Na deklarowaną chęć dzietności w rodzinie miało wpływ wiele czynników, jednym $z$ nich to obecna liczba dzieci $w$ rodzinie. Wiele badanych rodzin to rodziny z dwojgiem dzieci, stąd też tak duża liczba odpowiedzi wyrażająca chęć posiadania takiej własnej rodziny. Innym czynnikiem byla wielkość rodziny pochodzenia i wynikające $\mathrm{z}$ tego relacje między rodzeństwem. Im liczniejsza byla ta rodzina, tym większa chęć posiadania rodziny wielodzietnej. Przykładem do chęci posiadania trojga i więcej dzieci mogą być wypowiedzi bezrobotnych respondentów: Odpowiada mi liczna rodzina, gdyż w takiej się, wychowałem, $W$ rodzinie wielodzietnej jest wesoło. Równie ważnym czynnikiem wpływającym na wybór dzietności byla zła sytuacja finansowa rodziny wynikająca z zaistnialego bezrobocia męża, a w niektórych wypadkach obojga małżonków. Potwierdzają to następujące odpowiedzi badanych: $W$ obecnej sytuacji nie możemy pozwolić sobie na licznq rodzinę, Chce mieć tyle dzieci ze wzglę dów finansowych. Wypowiedzi te były w większości wyglaszane przez ojców jednego bądź dwojga dzieci i odnosily się głównie do rodzin z małym stażem małżeńskim, co oznacza głównie to, że jeszcze przez długi czas będą utrzymywać swoje dzieci. Ich sytuacja materialna pogorszyła się w związku z bezrobociem dlatego poprzez ograniczenie liczby dzieci chcieliby podnieść poziom swojego życia lub polepszyć warunki materialne dzieci już urodzonych.

Chcąc zbadać wpływ bezrobocia na dzietność w rodzinie, zadano także respondentom pytania dotyczące obecnej jak i planowanej w przeszłości chęci dzietności w rodzinie. I tak $17 \%$ respondentów chciało przed bezrobociem powiększyć rodzinę. W związku z bezrobociem plany te uległy zmianie i decyzję tę potwierdzilo już tylko $7,1 \%$ badanych.

Wykres nr 1. Plany dotyczące dzietności rodziny według opinii męża przed bezrobociem

Czy przed tym, gdy stracił pan prace planowaliście Państwo powiększyć rodzinę?

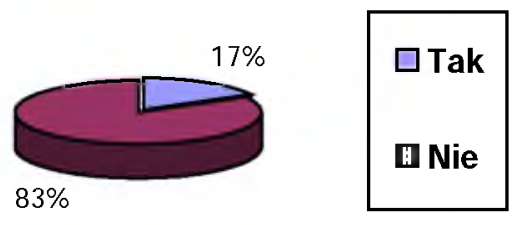

Źródło: Badania własne 
Wyniki badań potwierdzają wcześniejsze już wypowiedzi, w których ograniczano liczbę dzieci w rodzinie, powolując się na względy finansowe. $W$ tym kontekście, prokreacja, rodzicielstwo, wychowanie dziecka i sposób jego traktowania staje się bardziej niż kiedykolwiek przedmiotem wyboru jednostki, a więc każdego z partnerów małżeństwa. Tak więc wolny wybór pociąga za sobą kalkulowanie kosztów i korzyści, zysków i strat, a zatem rozpatrywanie „dobrych” i „zlych" stron faktu posiadania dziecka i samego rodzicielstwa ${ }^{10}$.

Wykres nr 2. Plany dotyczące powiększenia rodziny w trakcie bezrobocia

Czy obecnie planuje Pan wraz żonq powię kszyć rodzinę?

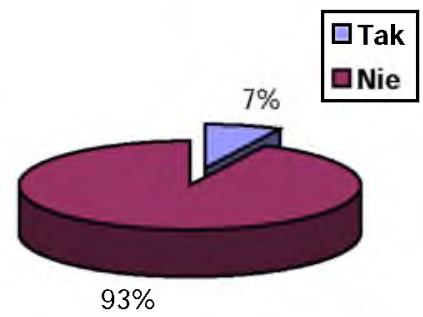

Źródło: Badania własne

\section{Cechy współmałżonka}

Zestaw cech wzorowego współmałżonka ściśle wiąże się ze sferą wartości, zarówno męża jak i żony oraz wartości rodzinnych. W rodzinach panują różne reakcje i zachowania, które charakteryzują stosunki wewnątrzrodzinne. Różnicują się także one $z$ prostego faktu fizyczno-psychicznej odmienności kobiety i mężczyzny oraz odmienności ról pełnionych w rodzinie przez matkę i przez ojca. Po określeniu przez badanych walorów idealnego męża i żony, odpowiedzi respondentów pogrupowano i skategoryzowano. $Z$ przedstawionych cech tych wynika, że najbardziej cenione są: „opiekuńczość/troskliwość” (18,5\%), a w następnej kolejności wyrażenie uczuć czyli zdolność i okazywanie kochania $(15,1 \%)$ oraz „czułość/dobroć" $(12,2 \%)$. Cechy te stanowią podstawę rozwoju emocjonalnej sfery życia rodziny i miłości zarówno między małżonkami jak i w

${ }^{10}$ J. R o s t o w s k i: Wspótczesne zmiany w postawach wobec dziecka. „Problemy Rodziny”. R. 1993 nr 5 s. $3-5$. 
kontekście rodzice - dzieci. Wartości te mają charakter uniwersalny i cenione sa przez prawie połowę badanych (Tab. 3).

Następne dwie cechy wskazane przez respondentów to: „dbałość o dom” $(10,4 \%)$ i "pracowitość" $(8,1 \%)$. Oznacza to, że bycie dobrym gospodarzem, gospodynią oraz utrzymanie domu są ważnymi zaletami męża i żony. Trzeba dodać, że pierwsza z tych cech była głównie wymieniana przez męża, dla którego troska o dom była bardzo ważna. Druga natomiast, tj. „pracowitość” była ceniona przez żony, co jest zrozumiałe, wziąwszy pod uwagę fakt pozostania na bezrobociu męża, a co za tym idzie problemy finansowe rodziny.

Kolejne trzy cechy czyli: „wyrozumiałość”, „zaradność” oraz „wychowanie dzieci" to cechy o nieco mniejszym znaczeniu, lecz równie ważne we wzorowym wizerunku partnera. Do cech tych większe znaczenie przywiązywali głównie bezrobotni mężczyźni, dla których była ważna wyrozumiałość, zwłaszcza ze strony żony, w tym trudnym dla nich okresie. Także według większości badanych respondentów, wzorowa żona, to taka, która potrafi zadbać o dom i zająć się dziećmi. Zdecydowanie cechy te nie charakteryzują układu partnerskiego w diadzie małżeńskiej. Natomiast takie cechy jak „inteligencja” czy „radość z życia" podkreślane także przez niektórych badanych świadczą o dużej więzi intelektualnej i emocjonalnej, a dominują one zwłaszcza w małżeństwach młodych.

Ostatnia grupa cech należy do najrzadziej wymienianych w modelu idealnego współmałżonka, a są to: „odpowiedzialność” i „zadbanie o siebie”. Pierwsza z tych cech była tylko wymieniana przez żony, co ma oczywiście swoje odbicie w sytuacji bezrobocia męża, które wpłynęło na sytuację w rodzinie. Natomiast druga, wskazana byla głównie przez mężów, którzy chcieli widzieć swoje żony, zadbane, dobrze ubrane itp. Trzeba także zwrócić uwagę na fakt zaistniałej trudności w zdefiniowaniu cech współmałżonka uważanych za ważne w małżeństwie, które dotyczyło 9 bezrobotnych mężów i 7 żon.

Tabela nr 2. Cechy wzorowej żony i wzorowego męża

\begin{tabular}{||l|c|c|c|c|c|c||}
\hline \multirow{2}{*}{$\begin{array}{l}\text { Jakie Pana/Pani zdaniem cechy } \\
\text { powinna mieć wzorowa żona/maż̇ }\end{array}$} & \multicolumn{3}{|c|}{ Maż $\mathrm{N}=112$} & \multicolumn{2}{c||}{ Żona $\mathrm{N}=112$} & \multicolumn{2}{c|}{$\begin{array}{c}\text { Ogółem } \\
\mathrm{N}=224\end{array}$} \\
\cline { 2 - 7 } & $\mathrm{L}$ & $\%$ & $\mathrm{~L}$ & $\%$ & $\mathrm{~L}$ & $\%$ \\
\hline Kochajaca & 40 & 15,7 & 27 & 14,2 & 67 & 15,1 \\
\hline Czuła/dobra & 17 & 6,7 & 37 & 19,5 & 54 & 12,2 \\
\hline Dbajaca o dom & 44 & 17,3 & 2 & 1,1 & 46 & 10,4 \\
\hline Wychowująca dzieci & 31 & 12,2 & 0 & 0 & 31 & 6,9 \\
\hline Opiekuńcza/troskliwa & 34 & 13,4 & 48 & 25,3 & 82 & 18,5 \\
\hline Zaradna & 23 & 9,1 & 8 & 4,2 & 31 & 6,9 \\
\hline Wyrozumiała & 30 & 11,8 & 4 & 2,1 & 34 & 7,7 \\
\hline Zadbana & 6 & 2,4 & 1 & 0,5 & 7 & 1,6 \\
\hline
\end{tabular}




\begin{tabular}{||l|c|c|c|c|c|c||}
\hline Pracowity/pracowita & 0 & 0 & 36 & 18,9 & 36 & 8,1 \\
\hline Odpowiedzialna/odpowiedzialny & 0 & 0 & 7 & 3,7 & 7 & 1,6 \\
\hline $\begin{array}{l}\text { Inne np. radosna, wierna, uczciwa, } \\
\text { inteligentna }\end{array}$ & 20 & 7,9 & 13 & 6,8 & 33 & 7,4 \\
\hline Nie wiem & 9 & 3,5 & 7 & 3,7 & 16 & 3,6 \\
\hline Razem & 254 & 100 & 190 & 100 & 444 & 100 \\
\hline
\end{tabular}

Źródło: Badania własne. Pytania nie sumują się do 112 gdyż respondenci mieli możliwość wyboru kilku odpowiedzi

$\mathrm{Z}$ analiz tych wynika, że mimo bezrobocia zaistnialego $\mathrm{w}$ rodzinie czynnik ekonomiczny przejawiajacy się w odpowiedzi „pracowitość" nie stanowil głównej cechy wyznaczającej idealnego współmałżonka. Zdecydowanie najważniejsze dla wielkomiejskich bezrobotnych rodzin $\mathrm{z}$ wykształceniem zawodowym i podstawowym są takie cechy, które związane są z trwałością i jakością związku małżeńskiego. Porównując odpowiedzi mężów i żon w zakresie częstotliwości wskazań oraz preferencji większości cech widać znaczną ich heterogeniczność. Cechy te stoją niejako w opozycji do istoty malżeństwa partnerskiego, w którym ojciec troszczy się o dom, matka wykonuje drobne prace domowe i wspóluczestniczy z mężem w zagwarantowaniu bytu rodzinie. Wszelkie decyzje sa podejmowane wspólnie, przed uprzednim porozumieniu. Trwałość związku opiera się na wzajemnej atrakcyjności partnerów, które ma dominować nad koniecznością podporządkowania się zadaniom i trudom życia rodzinnego ${ }^{11}$.

Cechy, które spotkały się z wyraźnie odmienną oceną mężczyzn i kobiet to: „dbanie o dom”, „wychowanie dzieci”, „pracowitość”. Pierwsze dwie zalety zdecydowanie częściej wybierali mężowie. Natomiast żony uważały, że wzorowy mąż powinien przede wszystkim być czlowiekiem, który potrafi zadbać o dom i go utrzymać.

Tabela nr 3. Najbardziej różnicujące cechy idealnego współmalżonka

\begin{tabular}{|l|c|c|}
\hline Cechy wspólmałżonka & Maż (dane w \%) & Żona (dane w \%) \\
\hline Dbanie o dom & 17,3 & 1,1 \\
\hline Wychowywanie dzieci & 12,2 & 0 \\
\hline Pracowitość & 0 & 18,9 \\
\hline
\end{tabular}

Źródło: Badania własne

W systemie cech idealnego wspólmałżonka widać wyraźnie ich odmienny charakter. Na tej podstawie można stwierdzić istnienie zróżnicowanego modelu

${ }^{11}$ Koncepcje E. B urgessa i H.J. L o cke`a zostala przedstawiona za - I. T a r a n o w i c z: Malżeństwo partnerskie - mit czy rzeczywistość. „Roczniki Socjologii Rodziny”. T. 3: 1991 s. $227-228$. 
małżonka w wielkomiejskiej rodzinie bezrobotnej, w którym mieszają się cechy zarówno małżeństwa tradycyjnego jak i nowoczesnego (partnerskiego) ${ }^{12}$.

\section{Przekaz wartości rodzice - dzieci}

Wpływ rodziny na rozwój psychiki dziecka jest znaczący. Celem aktywności wychowawczej rodziców jest wszechstronny - fizyczny, psychiczny, intelektualny, duchowy, moralny, społeczny i kulturowy rozwój dziecka. To we własnej rodzinie, od swoich własnych rodziców dziecko uczy się m.in. mówienia, działania i myślenia. Rodzice poprzez zamierzone oddziaływania opiekuńczowychowawcze przyczyniają się do rozwoju dziecka. Także na jego rozwój maja wpływ niezamierzone stosunki uczuciowe, które wynikają z interakcji zachodzących między rodzicami, a także poprzez ich wzory osobowe. Rodzice przekazuja dziecku wartości, normy, morale i wzory zachowań oraz obyczaje kulturowe, moralne i religijne społeczeństwa, do którego sama należy. Przekazuje więc dziecku, niekiedy bez głębszej refleksji, skalę i wiedzę ocen społeczeństwa, którego czlonkiem się staje $\mathrm{w}$ drodze socjalizacji rodzinnej. Przekaz ten staje się niezmiernie skomplikowany w okresie transformacji systemowej w państwie i w społeczeństwie, kiedy to wszelkie autorytety oraz systemy znaczen są zachwiane w swych strukturach i funkcjonowaniu. Sytuację taką obserwujemy obecnie w Polsce, gdzie wiele czynników, a m.in. bezrobocie nie pozostaje bez wpływu na rozwój i wychowanie dzieci w ich środowiskach rodzinnych ${ }^{13}$.

Należy podkreślić, iż w przekazie wartości miedzy rodzicami a dziećmi ważną rolę pełni postawa dziecka wobec rodziców, to czy darzy ich ono szacunkiem i zaufaniem, czy stanowią oni dla dziecka wlaściwy model do naśladowania. W przekazie systemu wartości dużą rolę odgrywają procesy społecznego uczenia się, modelowania i identyfikacji. W miarę rozwoju intelektualnego dziecko poznaje nowe pojęcia i zaczyna się nimi posługiwać w sposób bardziej swobodny. Międzypokoleniowy przekaz wartości - od rodziców do potomstwa można określić mianem dziedziczenia społecznego, które przebiega w dwóch kierunkach: pozytywnym, jak i negatywnym. Dzieci wywodzące się z rodzin o zaburzonym stylu funkcjonowania, w których ma miejsce m.in. przemoc fizycz-

\footnotetext{
${ }^{12} \mathrm{Na}$ temat rodziny partnerskiej wypowiedzieli się m.in.: M. J a r o s z: Dezorganizacja w rodzinie i społeczeństwie. Warszawa 1987 s. 124 ; A. K o tla r s k a-M i ch a $1 \mathrm{~s} \mathrm{k}$ a: Życie rodzinne wielkomiejskich małżeństw $w$ wieku emerytalnym. Poznań 1985 s. 55; Z. T y s z k a: Partnerstwo $w$ małżeństwie jako sposób współżycia w rodzinie. „Rodzina i Szkoła”. R. $1985 \mathrm{nr}$ 8. Można przyjąć, że wspólnym dla powyższych wypowiedzi jest przyjęcie podobnego udziału w życiu rodzinnym obojga małżonków, jako cechy szczególnej nowego typu małżeństwa nazwanego partnerskim.

${ }^{13}$ J. B a n i a k: Rodzina a osobowość dziecka. „Problemy Rodziny”. 1996 nr 4 s. 19.
} 
na, alkoholizm, stając się rodzicami, często ujawniają tendencje do powielania tych samych wzorców zachowań, jak również preferują ten sam system wartości, $\mathrm{z}$ jakim zetknęly się $\mathrm{w}$ swojej rodzinie pochodzenia. Klimat, jaki panuje w rodzinie ma istotne znaczenie na proces socjalizacji dzieci. Warto wspomnieć, że w co piątej rodzinie sprzeczki, kłótnie i awantury są wynikiem nadużywania alkoholu przez któregoś $\mathrm{z}$ jej członków ${ }^{14}$. Wśród różnego rodzaju zjawisk konfliktogennych duże znaczenie odgrywa bezrobocie kogoś z rodziny oraz związane z tą sytuacją trudności finansowe. Nieporozumienia i konflikty zdarzają się w większości rodzin, ale nasilenie, częstość ich występowania stanowi problem glównie w rodzinach bezrobotnych $(39 \%)$ i respondentów oceniających swą sytuację materialną za złą $(25 \%)^{15}$.

We wzajemnym układzie więzi osobowych dorośli wzbogacają dziecko, ono zaś pogłębia ich dojrzałość. Kierunek i poziom rozwoju dziecka zależą od treści i sposobów zaspokajania jego potrzeb ${ }^{16}$, od tego, na jakich potrzebach koncentruja się wysiłki osób sprawujących opiekę nad dzieckiem. Potrzeby są czynnikami prawidłowo przebiegającego rozwoju dziecka, jeżeli są zaspakajane w sposób zadawalający i to we wszystkich wymiarach. Istnieje wiele wartości ważnych dla czlowieka np. wartości twórcze, wartości przeżyte albo doznawane (osiągane przez literaturę, sztukę), miłość czy wartości postawy ${ }^{17}$.

\section{Wykształcenie}

Bieda $\mathrm{w}$ rodzinach bezrobotnych wyostrza problemy związane $\mathrm{z}$ wykształceniem dzieci. Przeprowadzone badania wskazały, iż respondenci świadomi obecnych trudności na rynku pracy pragnęli zapewnić swym dzieciom wykształcenie z reguly wyższe niż sami posiadali. Najwięcej respondentów chciało, aby dziecko zdobyło wykształcenie wyższe $(34,6 \%)$, natomiast o wykształceniu średnim mówiło $15,2 \%$. Natomiast $17 \%$ badanych uważało, że wykształcenie jakie zdobędzie dziecko zależy głównie od niego samego ${ }^{18}$ czyli od jego zdolności, uporu, zaangażowania a 13,4\% bezrobotnych mężów stwierdziło, że powin-

${ }^{14}$ Komunikat CBOS Przejawy dysfunkcyjności rodzin. Warszawa, listopad 1994.

${ }^{15}$ Komunikat CBOS Nieporozumienia i konflikty w rodzinie, grudzień 1994.

${ }^{16}$ Pojecie „potrzeba” zostało zaczerpnięte z ekonomii i przeniesione później m.in. do socjologii, gdzie najczęściej jest rozumiane jako brak lub niedosyt czegoś, wprowadzający jednostkę w stan pragnienia owego czegoś i pobudzający do osiągnięcia określonego przedmiotu lub stanu, który w odczuciu jednostki usuwa ów brak lub wypełnia niedosyt (L. D y c ze ws k i: Stopień zaspokajania potrzeb podstawowych a rozwój potrzeb duchowych. W: Dziecko we wspótczesnej Polsce. Tom 2. Red. J. K o m o r o w s k a. Warszawa 1991).

${ }^{17}$ Tamże, s. 8-9

${ }^{18} \mathrm{O}$ indywidualizacji dzieci w rodzinie, która charakteryzuje się uniezależnieniem się pozycji dzieci w rodzinie i usamodzielnienie się w wyborze zawodu, wykształcenia - zob. J. T u r o w sk i: Teoria indywidualizacji, dz. cyt., s. 198-199. 
no to być takie wykształcenie, które zapewni pracę. 19,6\% badanych uważało, że jest jeszcze dużo czasu, aby myśleć o wykształceniu swoich dzieci, odpowiedzi te dotyczyly głównie rodzin, których dzieci były jeszcze małe.

Tabela nr 4. Model oczekiwanego wyksztalcenia dzieci przez ojca

\begin{tabular}{|l|c|c||}
\hline \multirow{2}{*}{$\begin{array}{l}\text { Jak wysokie wykształcenie powinno } \\
\text { zdobyć pana dziecko? }\end{array}$} & $\mathrm{L}$ & Mąż (N=112) \\
\cline { 2 - 3 } & 17 & 15,2 \\
\hline \hline Średnie & 39 & 34,8 \\
\hline Wyższe & 19 & 17 \\
\hline To zależy od dziecka & 15 & 13,4 \\
\hline Dające prace & 22 & 19,6 \\
\hline Za wcześnie o tym mý́leć & \multicolumn{2}{|c||}{} \\
\hline
\end{tabular}

Żródło: Badania własne

Badania dotyczące postawy w stosunku do wykształcenia dzieci ze strony ojca ukazały wpływ bezrobocia na jego zmianę. $11,6 \%$ bezrobotnych ojców potwierdziło zmianę swojej decyzji w sprawie wykształcenia dzieci, podwyższając je.

Tabela nr 5. Zmiany w opinii wyksztalcenia dzieci wg ojca

\begin{tabular}{|c|c|c|c|c|}
\hline \multirow{4}{*}{$\begin{array}{l}\text { Czy tak samo sadził Pan przed } \\
\text { bezrobociem? }\end{array}$} & \multicolumn{4}{|c|}{ Mąż } \\
\hline & \multicolumn{2}{|c|}{ Tak } & \multicolumn{2}{|c|}{$\mathrm{Nie}$} \\
\hline & $\mathrm{L}$ & $\%$ & $\mathrm{~L}$ & $\%$ \\
\hline & 99 & 88,4 & 13 & 11,0 \\
\hline
\end{tabular}

Żródło: Badania własne

Rodzice widząc problem na rynku pracy starają się wpływać na podnoszenie kwalifikacji zawodowych swoich dzieci. Jednak często zubożenie powoduje ograniczenie lub niemożność inwestowania w rozwój i wykształcenie młodego pokolenia, które mówi o jakości kapitału ludzkiego, będącego współcześnie podstawowym czynnikiem rozwoju gospodarczego i cywilizacyjnego ${ }^{19}$.

\section{Kultura}

Rozwój osobowości jednostek i rozwój całej kultury zależy w dużym stopniu od jakości potrzeb ${ }^{20}$. Dziecko musi doznawać wielu różnorodnych przeżyć,

${ }^{19}$ D. Grani ews ka: Rodzina a bezrobocie. Sytuacja w Polsce. W: Wspótczesne rodziny polskie - ich stan i kierunki przemian. Red. Z. T y s z k a. Poznań 2001 s. 340.

${ }^{20}$ Wśród koncepcji i typologii podziałów stylu życia w Polsce uwagę zwraca charakterystyka stylu zunifikowanego nazwanego stylem społeczeństwa masowego. Jego cechą jest bezstylowość i brak własnych charakterystycznych zachowań. Jest to styl, który dominuje wśród ludności miejskiej, zdeterminowany rytmem życia. Jest to tło kulturowe, na którym opierają się dzisiejsze aspira 
powinno stykać się wciąż z nowymi treściami, które pobudzałyby je uczuciowo i umyslowo. Powinno tworzyć nowe treści i formy, które wywoluja nowe doświadczenia. Takiemu pobudzaniu do twórczości pomaga zaangażowanie rodziców w sprawy innych ludzi oraz sprawy publiczne i wciaganie w nie dzieci.

Chcąc zbadać, jak wygląda aktywność wielkomiejskich bezrobotnych rodzin z wykształceniem zawodowym i podstawowym proszono badanych o podanie rozkładu wydatków miesięcznych. Respondenci mieli możliwość zaznaczenia kilku odpowiedzi w ramach 9 kategorii. Najwięcej pieniędzy z budżetu rodzinnego w skali miesiąca przeznaczano na wyżywienie (29,8\%) i mieszkanie $(29,5 \%)$. Następnie w kolejności wymieniano zakup odzieży $(14,4 \%)$ oraz tzw. „stały wydatek” $(7,3 \%)$, który dotyczył glównie stałych comiesięcznych wydatków na samochód. Zdecydowanie mniej pieniędzy przeznaczano na rozrywki kulturalne $(5,2 \%)$, kieszonkowe dla dzieci $(4,9 \%)$ i udział w życiu towarzyskim $(4,6 \%)$. Minimalna część przychodów miesięcznych rodziny byla przeznaczana na hobby $(1,9 \%)$ i wypoczynek $(1,9 \%)$.

W sytuacji, kiedy większość wydatków (59,3\%) przeznaczana jest na wyżywienie i mieszkanie trudno mówić o udziale w aktywnym życiu towarzyskim i kulturalnym przez zbadane rodziny. Bezrobocie i związane $z$ nim przemiany doprowadzily do sytuacji, w której rodzina w nie jest $w$ stanie pełnić swych funkcji w dotychczasowym zakresie i musi je ograniczyć. Bezrobotna rodzina wielkomiejska zaprzestała zupełnie lub dzieli wykonanie funkcji z innymi instytucjami $^{21}$. Chodzi tu głównie o wychowanie i kształcenie dzieci, opiekę nad poszczególnymi członkami rodziny, sferę działalności gospodarczej, kulturalnorozrywkowej i kształtowanie systemu norm i wartości regulujących zachowania.

Postawiona zatem hipoteza zakładająca, iż współczesna rzeczywistość spoleczno-ekonomiczna nie sprzyja pełnieniu funkcji rodzicielskich, okazała się prawdziwa.

\section{Tradycja}

Środowisko rodzinne powinno tworzyć korzystny klimat dla zaspokojenia i rozwoju potrzeb dziecka. Udaje się to realizować w sposób harmonijny wówczas, gdy oboje rodzice m.in. z pietyzmem przechowuja pamiątki i tradycje ro-

cje dotyczące czasu wolnego i wypoczynku. Uzależniony jest on w dużej mierze od podłoża ekonomicznego, zawodowego i demograficznego (A. Woźn i a k: Turystyka $w$ stylu życia wspótczesnych Polaków. W: Między przeszłościq a przyszlościa. Szkice o socjologii i spoleczeństwie polskim w dobie przemian ustrojowych. Red J. W 1 o d a r e k. Poznań 1998 s. 301-307).

${ }^{21}$ R. S k r z y p n i a k: Rodzina - mała ojczyzna wychowawcza. „Roczniki Socjologii Rodziny". T. 10: 1998 s. $199-218$. 
dzinne. Z badań wynika, że w zdecydowanej większości $(92,9 \%)$ badanych rodzin przekazuje się tradycji $\mathrm{w}$ rodzinie. Tylko $6,2 \%$ rodzin nie potwierdziła uczestnictwa w kultywowaniu tradycji.

Wpajanie przez rodziców potomstwu tradycji rodzinnej, narodowej spowodowane jest ogólnie wysoką rangą rodziny w naszej kulturze, spoleczeństwie jak i mentalności poszczególnych jednostek. Najczęściej tego typu postawę przekazywały matki (44,6\%), w drugiej kolejności za przekaz ten byli odpowiedzialni oboje rodzice $(31,3 \%)$. Także w przekazie tradycji mieli udział członkowie rodziny np. teściowa, matka respondenta $(13,4 \%)$, znikomy udział w tym przekazie mial ojciec $(0,9 \%)$.

Tabela nr 6. Odpowiedzialność za przekaz tradycji w rodzinie

\begin{tabular}{|c|c|c|c|c|c|c|c|c|c|c|c|c|}
\hline \multirow{2}{*}{\begin{tabular}{|l} 
Kto jest odpo- \\
wiedzialny za \\
przekaz trady- \\
cji w rodzinie?
\end{tabular}} & \multicolumn{2}{|c|}{ Żona } & \multicolumn{2}{|c|}{ Mąż } & \multicolumn{2}{|c|}{$\begin{array}{l}\text { Wspólnie } \\
\text { małżonko- } \\
\text { wie }\end{array}$} & \multicolumn{2}{|c|}{$\begin{array}{l}\text { Inne (matka, } \\
\text { teściowa) }\end{array}$} & \multicolumn{2}{|c|}{ Nie dotyczy } & \multicolumn{2}{|c|}{ Ogółem } \\
\hline & $\mathrm{L}$ & $\%$ & $\mathrm{~L}$ & $\%$ & $\mathrm{~L}$ & $\%$ & $\mathrm{~L}$ & & $\mathrm{~L}$ & $\%$ & $\mathrm{~L}$ & $\%$ \\
\hline $\mathrm{N}=112$ & 50 & 44,6 & 1 & 0,9 & 35 & 31,3 & 15 & 13,4 & 11 & 9,8 & 112 & 100 \\
\hline
\end{tabular}

Żródło: Badania własne

Z powyższych danych wynika, że to matka w glównej mierze jest odpowiedzialna za kultywowanie tradycji w rodzinie. Stąd wysuwa się wniosek, że w wielkomiejskich rodzinach bezrobotnych $\mathrm{z}$ wykształceniem zawodowym i podstawowym żony/matki częściej niż inni członkowie rodziny wykazują troskę o pomyślność osobistą dziecka i tym samym nadaja mu większe znaczenie wychowawcze tego typu wartościa.

\section{Wartości postaw członków rodziny}

Nowe warunki, utworzone np. za sprawa bezrobocia w rodzinie tworza nową historię oraz teraźniejszość. Relacje rodzice - dzieci, choć krzyżują się nie tylko w indywidualnych rodzinach, ale i zbiorowości wymagają wyraźnego rozróżnienia,

Chcąc dowiedzieć się, jakie sa postawy rodziców względem dzieci, zapytano respondentów: Jakq role powinni spelniać rodzice $W$ stosunku do dzieci? Odpowiedzi respondentów pogrupowano i utworzono kategorie. 
Tabela nr 7. Postawy rodzicielskie

\begin{tabular}{|c|c|c|c|c|c|c|}
\hline \multirow{2}{*}{$\begin{array}{l}\text { Jaką rolę powinni spełniać } \\
\text { rodzice w stosunku do dzie- } \\
\text { ci? }\end{array}$} & \multicolumn{2}{|c|}{ "Mąż ( $\mathrm{N}=112)$} & \multicolumn{2}{|c|}{ "Żona $(\mathrm{N}=112)$} & \multicolumn{2}{|c|}{ Ogółem } \\
\hline & $\mathrm{L}$ & $\%$ & $\mathrm{~L}$ & $\%$ & $\mathrm{~L}$ & $\%$ \\
\hline Wychowawcza & 54 & 30,5 & 44 & 24,4 & 98 & 27,5 \\
\hline $\begin{array}{l}\text { Powinni je utrzymy- } \\
\text { wać/zapewnić byt }\end{array}$ & 16 & 9 & 22 & 12,2 & 38 & 0,6 \\
\hline $\begin{array}{l}\text { Wspierać w trudnych chwi- } \\
\text { lach/otaczać opieką }\end{array}$ & 37 & 20,9 & 37 & 20,6 & 74 & 20,8 \\
\hline $\begin{array}{l}\text { Powinni dawaé dobry przy- } \\
\text { klad }\end{array}$ & 24 & 13,6 & 22 & 12,2 & 6 & 12,9 \\
\hline $\begin{array}{l}\text { Dzieci powinny być posusz- } \\
\text { ne rodzicom /szanować ich }\end{array}$ & 18 & 10,2 & 10 & 5,5 & 28 & 7,9 \\
\hline Powinni je kochać & 7 & 3,9 & 11 & 6,1 & 18 & 5,0 \\
\hline Powinni dać wykształcenie & 5 & 2,8 & 8 & 4,4 & 13 & 3,6 \\
\hline $\begin{array}{l}\text { Powinni przekazywać warto- } \\
\text { ści/tradycję }\end{array}$ & 0 & 0 & 16 & 8,9 & 16 & 4,5 \\
\hline $\begin{array}{l}\text { Inne (rozmawiać, kontrolo- } \\
\text { wać, być nauczycielami) }\end{array}$ & 9 & 5,1 & 9 & 5 & 18 & 5,0 \\
\hline Trudno powiedzieć & 6 & 3,4 & 0 & 0 & 6 & 1,7 \\
\hline Brak odpowiedzi & 1 & 0,6 & 1 & 0,6 & 2 & 0,6 \\
\hline Razem & 177 & 100 & 180 & 100 & 357 & 100 \\
\hline
\end{tabular}

Żródło: Badania własne

Sama osobowość rodziców, jak również relacje między nimi a dzieckiem, wpływa w mniejszym lub większym stopniu na działania wychowawcze podejmowane przez rodzinę. Jak wykazano (Tab.7) na niektóre wartości w wychowaniu rodzinnym większy nacisk kłada ojcowie, a na inne matki. Dotyczą one zwłaszcza roli wychowawczej, która była częściej wymieniana przez mężów $(30,5 \%)$ niż żony $(24,4 \%)$. Z kolei przekaz tradycji i ważnych wartości był uwzględniany tylko w wypowiedziach żon $(8,9 \%)$, żaden mąż nie stwierdził istotności tej kategorii w kształtowaniu postaw względem dzieci. Fakt ten zwiazany jest głównie $\mathrm{z}$ tym, że za kultywowanie obrzędów w rodzinie głównie odpowiedzialna jest żona, dlatego to ona dostrzega istotność tradycji w rodzinie. Także różnice widać w stosunku do szacunku i posłuszeństwa dzieci względem rodziców. Owa kategoria była częściej wymieniana przez mężów/ojców $(10,2 \%)$ niż żony/matki $(5,6 \%)$.

W świetle powyższych danych widać, że rola matki w badanych rodzinach związana jest przede wszystkim z rozwijaniem dobroci i miłości wśród dzieci. Potwierdzaja to następujace wypowiedzi respondentek: Rodzina to najważniejsza wartość, tutaj kształtuje się młode pokolenie, rozwiqzuje się wiele spraw, kłopotów. Rodzice to najlepsi przyjaciele, na których można polegać oraz Rodzi- 
ce powinni troszczyć się o dzieci i zapewnić im przyszłość. Matka zajmuje się wychowaniem w tradycji oraz czuwa nad rozwojem intelektualnym swoich dzieci. Rola ojca polega natomiast na doskonaleniu charakteru dzieci, gdzie najpierw ważne są obowiązki, szacunek i posłuszeństwo, a potem dopiero postawy moralne.

Chcąc zbadać postawę czlonków rodzin względem bezrobotnego ojca/męża, proszono badanych o udzielenie odpowiedzi na pytanie związane $\mathrm{z}$ poziomem akceptacji tej właśnie osoby. Swój pogląd wyrażali oni na pięciostopniowej skali: od stanowiska najbardziej zdecydowanego i pozytywnie ustosunkowanego do bezrobotnego męża/ojca, poprzez stopnie pośrednie, do postawy zdecydowanie negującej. I tak, zdecydowana większość żon nie akceptowała swojego męża na bezrobociu (66\%). Tylko 14,3\% badanych respondentek uważało, że „raczej akceptuje" swojego męża w zaistniałej sytuacji, a żadna z nich nie udzieliła pełnej, zdecydowanej akceptacji.

Tabela nr 8. Postawa akceptacji bezrobotnego męża wg opinii żon

\begin{tabular}{||l|c|c||}
\hline \multirow{2}{*}{ Czyy akceptuje Pani męża? } & \multicolumn{2}{|c|}{$\mathrm{N}=112$} \\
\cline { 2 - 3 } & $\mathrm{L}$ & $\%$ \\
\hline Akceptuję całkowicie & 0 & 0 \\
\hline Raczej akceptuję & 16 & 14,3 \\
\hline Trudno powiedzieć & 18 & 16,1 \\
\hline Raczej nie akceptuję & 37 & 33 \\
\hline Zupełnie nie akceptuję & 37 & 33 \\
\hline Brak odpowiedzi & 4 & 3,6 \\
\hline Ogólem & 112 & 100 \\
\hline
\end{tabular}

Żródło: Badania własne

Trzeba także zwrócić uwagę na fakt, iż 16,1\% respondentek nie potrafiło określić swojej postawy względem męża, co sygnalizuje na pewne problemy $z$ zdefiniowaniem wzorca co do zaistniałej sytuacji.

W przeprowadzanych badaniach nie brały udziału dzieci, stąd chcac dowiedzieć się o ich postawę w stosunku do bezrobotnego ojca, pytanie dotyczace stopnia akceptacji w tej kwestii zostało skierowane właśnie do niego. Dla porównania zapytano także bezrobotnych respondentów o odczuwalny poziom akceptacji ze strony ich żon. W opinii mężów/ojców, w wyniku zaistniałej sytuacji, jakim stało się bezrobocie, żony częściej przejawiaja postawę braku akceptacji $(71,4 \%)$ niż dzieci $(53,6 \%)$. Całkowicie akceptuje go 3,6\% żon jak i dzieci, jednak w przypadku skrajnego braku akceptacji ponownie dominują żony $(29,5 \%)$ nad dziećmi $(20,6 \%)$. 
Tabela nr 9. Rozkład postawy akceptacji czlonków rodziny względem bezrobotnego męża/ojca

\begin{tabular}{||l|c|c|c|c||}
\hline \multirow{2}{*}{$\begin{array}{l}\text { Jak Pan sądzi, jak kształtuje się postawa } \\
\text { akceptacji w stosunku do Pan jako bezro- } \\
\text { botnego? }\end{array}$} & \multicolumn{2}{|c|}{ Żona } & \multicolumn{2}{c||}{ Dziecko } \\
\cline { 2 - 5 } & $\mathrm{L}$ & $\%$ & $\mathrm{~L}$ & $\%$ \\
\hline Akceptuje całkowicie & 4 & 3,6 & 4 & 3,6 \\
\hline Raczej akceptuje & 12 & 10,7 & 7 & 6,2 \\
\hline Trudno powiedzieć & 15 & 13,4 & 33 & 29,5 \\
\hline Raczej nie akceptuje & 47 & 41,9 & 37 & 33 \\
\hline Zupełnie nie akceptuje & 33 & 29,5 & 23 & 20,6 \\
\hline Nie dotyczy & 0 & 0 & 7 & 6,2 \\
\hline Brak odpowiedzi & 1 & 0,9 & 1 & 0,9 \\
\hline Ogółem & 112 & 100 & 112 & 100 \\
\hline \hline
\end{tabular}

Żrôdło: Badania własne

Porównując wypowiedzi mężów oraz ich żon widać, że mężowie bardziej krytycznie oceniaja postawę względem siebie ze strony swoich żon $(71,4 \%)$, niż jest to w rzeczywistości $(66 \%)$. Analiza powyższych danych ukazuje także trudności w umiejętności poprawnej identyfikacji wzorca i wartości postaw uczestników życia rodzinnego. Problem ze wskazaniem poziomu akceptacji miało w sumie $42,9 \%$ badanych bezrobotnych. Podobny problem mialy także żony $(16,1 \%)$, na co zwrócono uwage już wcześniej. Potwierdza to więc hipotezę glówną zakladającą istnienie problemu w określeniu wzorca wychowawczego i socjalizacyjnego $\mathrm{w}$ wielkomiejskiej rodzinie bezrobotnej $\mathrm{z}$ wykształceniem zawodowym i podstawowym.

W badaniach brały udział wielkomiejskie rodziny, posiadające swoista specyfikę, która odróżnia je od innych środowisk. Charakterystyczne cechy wielkiego miasta to m.in.: duża ruchliwość jego mieszkańców, anonimowość i atomizacja a także mniejsze tendencje do konformizmu. Analiza dotyczyła przeobrażeń więzi wewnątrzrodzinnej wielkomiejskich rodzin bezrobotnych $z$ wykształceniem zasadniczym zawodowym i podstawowym, w odniesieniu do dwóch płaszczyzn:

- przekazu wartości wewnątrz diady małżeńskiej

- przekazu wartości rodzice - dzieci. 
Obiektem zainteresowań uczyniono, nawiązując do koncepcji Z. Tyszki, wzory społeczne, które reguluja funkcjonowanie określonego typu mikrogrup oraz ich podsystemów i elementów składowych ${ }^{22}$.

Kierunki zmian, jakim uległa rodzina we współczesnych spoleczeństwach obejmują przekształcenia, które polegały na przejściu od rodziny wielkiej trzypokoleniowej do rodziny nuklearnej, małej. Czyli było to przejście od rodziny produkcyjnej, gdzie podstawą utrzymania byla praca w rodzinnym warsztacie do rodziny samodzielnie się gospodarującej i niezależnej ekonomicznie, lecz bardziej narażonej ze względu na liczne przemiany, jakie mają miejsce w społeczeństwie. Chodzi tu głównie o występującą u nas transformację społecznoustrojową, która spowodowała liczne widoczne skutki w odniesieniu do rodziny $\mathrm{np}$. bezrobocie ${ }^{23}$. Zmiany te zachodzily i nadal zachodzą w różnym tempie $\mathrm{w}$ poszczególnych rodzinach.

Analiza związana była z więzią wewnątrzrodzinna, a w niej: modelu współmałżonka, pelnieniu funkcji rodzicielskich oraz określeniu wzorca wychowawczego i socjalizacyjnego. Założono w nich kolejno: niesprzyjający wplyw rzeczywistości społeczno-ekonomicznej na pelnienie funkcji rodzicielskich, zróżnicowanie modelu współmałżonka oraz brak określonego wzorca wychowawczego i socjalizacyjnego w badanych rodzinach. Wyniki badań pokazały trudności w realizacji wielu funkcji przez rodzinę, dotyczyło to m.in. takich funkcji jak: funkcja emocjonalno-ekspresyjna, ekonomiczna, socjalizacyjna, opiekuńczo-wychowawcza. W związku z powyższym pierwsza z wymienionych hipotez potwierdziła się.

Analizując preferowane wzorowe cechy współmalżonka, które deklarowali ankietowani widać wyraźną ich heterogeniczność. Dlatego można przyjać, że w wielkomiejskich rodzinach bezrobotnych panuje zróżnicowany model męża i żony. Badania potwierdzily także słuszność hipotezy zakładającej trudności w zdefiniowaniu wzorca wychowawczego i socjalizacyjnego badanej rodziny. Trudności te występowały głównie w definicji wartości postaw czlonków rodziny względem bezrobotnego męża/ojca.

${ }^{22}$ Z. T y s z k a: Stan i przeobrażenia, dz. cyt., s. 15-21.

${ }^{23}$ Z. T y s z k a: Rodzina polska w okresie transformacji spoleczno-ustrojowej. W: Miedzy przeszłościa a przyszlościa. Szkice o socjologii i społeczeństwie polskim $w$ dobie przemian ustrojowych. Red. J. W ł o d a r e k. Poznań 1998 s. 233-241. 